\title{
PEMILIHAN SISTEM PENGELOLAAN AIR LIMBAH DOMESTIK DI DAS CISANGKAN
}

\author{
EKA WARDHANI, ROSMEILIYANA \\ Program Studi Teknik Lingkungan, Fakultas Teknik Sipil dan Perencanaan \\ Institut Teknologi Nasional Bandung \\ Email: ekawardhani08@gmail.com
}

\begin{abstract}
ABSTRAK
Kota Cimahi merupakan wilayah penyumbang beban pencemaran yang besar terhadap Sungai Citarum. Terdapat 5 sungai di Kota Cimahi yang terindikasi tercemar berat diantaranya adalah Sungai Cisangkan. DAS Cisangkan ditempati oleh penduduk dengan kepadatan tinggi dan belum dilengkapi dengan sistem pengelolaan air limbah domestik. Penelitian ini bertujuan untuk mengetahui strategi pengendalian pencemaran air yang sesuai untuk Sungai Cisangkan. Pengendalian difokuskan kepada air limbah domestik sesuai dengan PerMenPUPR No. 4 Tahun 2017. Hasil penelitian menyebutkan bahwa mutu air Sungai Cisangkan masuk katagori cemar berat dengan parameter yang tidak memenuhi bakumutu diantaranya BOD, COD, TSS, Fecal coli dan Total Coli. DAS Cisangkan meliputi 10 kelurahan, berdasarkan hasil penapisan 7 diantaranya akan menerapkan sistem terpusat dan 3 kelurahan menerapkan sistem setempat. Pengelolaan secara terpusat akan menggunakan perpipaan yang akan menyalurkan ke instalasi pengolahan air limbah. Sistem setempat direncanakan dengan menggunakan tangki septik biofilter berkapasitas 200 kepala keluarga per unit.
\end{abstract}

Kata kunci: Sungai Cisangkan, limbah, domestik, pengelolaan

\begin{abstract}
Cimahi City is an area that contributes a large pollution load to the Citarum River. There are five rivers in Cimahi City that are indicated to be heavily polluted, including the Cisangkan River. The Cisangkan watershed is occupied by a high-density population and is not equipped with a domestic wastewater management system. This study aims to determine the appropriate water pollution control strategy for the Cisangkan River. Control is focused on domestic wastewater in accordance with the regulation of the Minister of Public Works and Public Housing No. 4/2017. The results stated that the quality of Cisangkan River water was categorized as heavily polluted with parameters that did not meet the quality standards, including BOD, COD, TSS, Fecal Coli and Total Coli. The Cisangkan watershed covers ten sub-districts; based on the results of the screening, 7 of them will implement a centralized system, and three villages will apply the local system. Centralized management will use piping that will supply the wastewater treatment plant. The local system is planned using a biofilter septic tank with a capacity of 200 households per unit.
\end{abstract}

Keywords: Cisangkan River, domestic, wastewater, management 


\section{PENDAHULUAN}

Sungai Cisangkan merupakan anak Sungai Citarum yang mengalir di sekitar Kota Cimahi. DAS Cisangkan dengan luas 1.238,09 hektar meliputi dua kecamatan yaitu Cimahi Tengah dan Cimahi Selatan. Kelurahan yang masuk DAS ini yaitu Padasuka, Kelurahan Setiamanah, Kelurahan Baros, dan Leuwigajah. Panjang Sungai Cisangkan yaitu 16,91 km (DIKLHD Kota Cimahi, 2020). Sungai Cisangkan bagian hulu memiliki lebar permukaan dan dasar $2 \mathrm{~m}$ kedalaman 0,2 $\mathrm{m}$ dan memiliki debit maksimum 0,99 $\mathrm{m}^{3} /$ detik dan minimum 0,02 $\mathrm{m}^{3} /$ detik. Bagian tengah memiliki lebar permukaan dan dasar $3 \mathrm{~m}$, kedalaman 0,3 m dengan debit maksimum $1,19 \mathrm{~m}^{3} /$ detik dan minimum $0,05 \mathrm{~m}^{3} /$ detik. Bagian tengah memiliki lebar permukaan dan dasar $6 \mathrm{~m}$, kedalaman saluran 0,7 meter dengan memiliki debit maksimum 2,24 $\mathrm{m}^{3} /$ detik dan minimum 0,3 $\mathrm{m}^{3} /$ detik (DIKLHD Kota Cimahi, 2020).

Aktivitas di DAS Cisangkan di dominasi oleh kegiatan domestik dan industri. Aktivitas domestik membutuhkan air sebagai penunjang, dimana $80 \%$ dari air tersebut akan menjadi limbah rumah tangga. Tahun 2019, tidak semua penduduk di Kota Cimahi memiliki sarana dan prasarana air limbah. Banyaknya Kepala Keluarga (Zorpas, Lasaridi, Voukkali, Loizia, \& Chroni) yang masih membuang limbah ke sungai atau tidak terlayani, baik oleh jamban pribadi, IPAL komunal, maupun MCK (DIKLHD Kota Cimahi, 2020). Dampak dari aktivitas domestik warga sekitar DAS menyebabkan Sungai Cisangkan menjadi salah satu sungai dengan beban pencemaran tertinggi di Kota Cimahi. Sungai Cisangkan mengalami pendangkalan yang diakibatkan oleh berkurangnya daerah resapan air. Air yang terbawa (air larian) oleh aliran hujan dan masuk ke dalam sungai menyebabkan adanya sedimentasi di dalam sungai, sehingga Sungai Cisangkan merupakan salah satu sungai di Kota Cimahi yang mengalami pendangkalan dan pencemaran tingkat kronis (DIKLHD Kota Cimahi, 2020).

Seperti halnya anak Sungai Citarum lainnya seperti Sungai Citarik, Cikijing, dan Cibaligo yang mengalami tekanan lingkungan yang sangat berat dari aktivitas penduduk yang ada di DAS. Kejadian tersebut menyebabkan kualitas air menurun dan mencemari Sungai Citarum yang berakhir di Waduk Saguling (Sulistiowati dan Wardhani, 2018), (Wardhani dan Sulistiowati, 2018), (Anggraini dan Wardhani, 2021). Tercemarnya Sungai Citarum berdampak pada berkurangnya fungsi Waduk Saguling (Wardhani dkk, 2014). Kualitas air dan sedimen waduk menjadi buruk karena menampung pencemar dari Sungai Citarum (Wardhani dkk, 2017a) (Wardhani dkk, 2017b). Beberapa logam berat terdeteksi di air dan sedimen yang akan menimbulkan pengaruh buruk pada ekologi waduk tersebut (Arinda dan Wardhani, 2018), (Wardhani dkk, 2018).

Sungai Citarum saat ini menjadi perhatian nasional karena kualitasnya yang sangat buruk, beberapa parameter terpantau tidak memenuhi baku mutu termasuk logam berat (Desriyan dan Wardhani, 2015), (Rachmaningrum dkk, 2015). Pemerintah pusat dengan Program Citarum Harum telah mengupayakan perbaikan kualitas air sungai khususnya sektor industri. Beban pencemaran dari sektor domestic juga perlu diperhatikan karena memberikan konstribusi yang signifikan. Pengendalian pencemaran dapat dilakukan dengan merencanakan Sistem Pengolahan Air Limbah Domestik (SPALD) dimana nantinya air limbah domestik disalurkan terlebih dahulu ke instalasi pengolahan air limbah (IPAL) untuk diolah sebelum nantinya akan dibuang ke sungai. Output yang diharapkan adalah beban pencemaran Sungai Cisangkan dapat menurun sehingga meningkatkan kualitas air sungai.

Tujuan penelitian ini untuk menentukan pengelolaan air limbah di DAS Cisangkan dari sektor domestik. Penelitian ini akan menentukan jenis SPALD yang paling tepat diterapkan berdasarkan kondisi DAS. Penelitian ini mengacu pada Peraturan Menteri Pekerjaan Umum 
dan Perumahan Rakyat No 4 tahun 2017 (Permen PUPR No. 4/2017) tentang penentuan SPALD. Kajian sejenis telah dilakukan di beberapa lokasi seperti di Kecamatan Beji Kota Depok (Wiguna dkk, 2019), Kecamatan Bekasi Timur, Kota Bekasi (Kusumawardhani dkk, 2019), dan Kecamatan Bekasi Selatan Kota Bekasi (Uyun dkk, 2019). Penelitian ini bermanfaat karena membantu pengambil keputusan untuk menentukan jenis SPALD dan prioritas pembangunannya.

\section{BAHAN DAN METODE}

\subsection{Metode Penelitian}

Tahapan penelitian ini meliputi studi pustaka, proses pengumpulan data, pengolahan dan analisis data, dan pemetaan wilayah yang cocok dilayani oleh SPALD baik terpusat maupun setempat. Studi pustaka merupakan tahapan awal dalam melakukan penelitian. Jenis pustaka yang dipelajari berupa buku teks, jurnal, berita, dan laporan penelitian. Data yang diambil pada penelitian ini merupakan data sekunder yang diperoleh dari instansi pemerintahan Kota Cimahi yaitu Dinas Lingkungan Hidup dan Kehutanan Kota Cimahi, kemudian data-data pendukung yang diambil dari berbagai sumber untuk mendukung analisis data. Adapun data sekunder yang mendukung penelitian ini antara lain: kualitas air Sungai Cisangkan, dokumen Rencana Tata Ruang Wilayah Kota Cimahi (RTRW) tahun 20112031, Rencana Pembangunan Jangka Menengah Daerah (RPJMD) Kota Cimahi.

Dasar pertimbangan penentuan jenis SPALD mengacu pada PerMen PUPR No. 4/2017 seperti disajikan pada Gambar 1 dengan data yang diperlukan untuk proses penapisan yaitu:

1. Kepadatan penduduk dengan kriteria jika $>150$ jiwa/Ha $\left(15,000\right.$ jiwa/ $\left.\mathrm{Km}^{2}\right)$ cocok menerapkan sistem SPALD-T, sebaiknya jika kurang dari 150 jiwa/Ha masih terdapat beberapa pertimbangan lainnya, seperti sumber air yang ada, kedalaman air tanah, permeabilitas tanah, kemiringan tanah, ketersediaan lahan, termasuk kemampuan membiayai.

2. Kedalaman muka air tanah digunakan sebagai kriteria dalam penetapan SPALD. Kondisi air tanah yang dangkal tidak cocok untuk diterapkan pada sistem pembuangan air limbah setempat (Aini, 2019). Muka air tanah lebih kecil dari $2 \mathrm{~m}$ atau jika air tanah sudah tercemar, digunakan SPALD-T.

3. Permeabilitas tanah sangat mempengaruhi penentuan jenis SPALD, khususnya untuk penerapan Sub-sistem Pengolahan Setempat (cubluk maupun tangki septik dengan bidang resapan). Cara untuk mengetahui besar kecilnya permeabilitas tanah dapat diperkirakan dengan memperhatikan jenis tanah dan angka infiltrasi tanah atau berdasarkan tes perkolasi tanah. Permeabilitas yang efektif yaitu $5 \times 10^{-4} \mathrm{~m} /$ detik dengan jenis tanah pasir halus sampai dengan pasir yang mengandung lempung (PerMenPUPR No. 4 tahun 2017).

4. Kemampuan pembiayaan dapat mempengaruhi pemilihan jenis SPALD, terutama kemampuan pemerintah daerah dalam membiayai pengoperasian dan pemeliharaan SPALD-T. SPALD yang nantinya akan dibangun akan digunakan oleh masyarakat setempat, sehingga harus memperhatikan juga keadaan ekonomi masyarakat sasaran pembangunan. Biaya operasional dan pemeliharaan alat-alat pengolahan air limbah tidak selalu ditanggung oleh pemerintah daerah setempat, oleh sebab itu perlu diadakannya pemberdayaan masyarakat setempat terkait dengan pembebanan biaya pembangunan dan operasional penyelenggaraan pengolahan air limbah (Aini, 2019).

5. Kemiringan tanah, penerapan jaringan pengumpulan air limbah domestik sesuai jika kemiringan tanah sama dengan atau lebih dari $2 \%$, sedangkan shallow sewer dan small bore sewer dapat digunakan pada berbagai kemiringan tanah. 


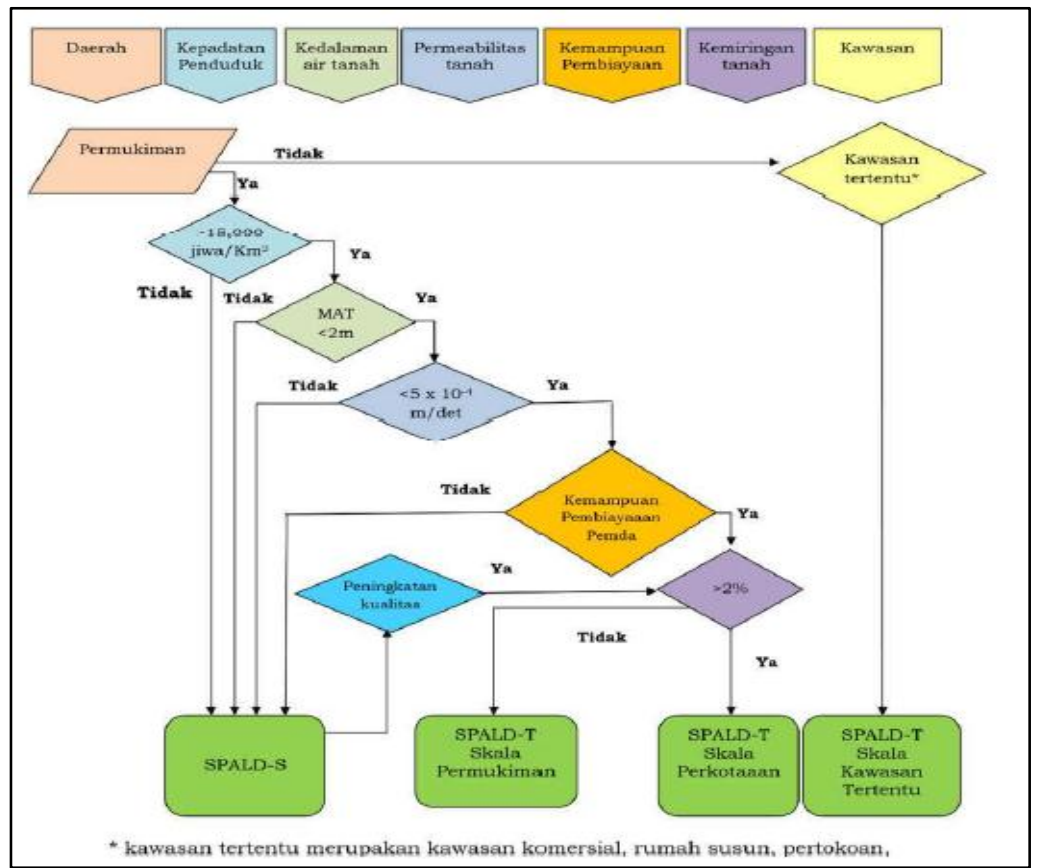

Gambar 1 Diagram Alir Penentuan Jenis SPALD (Sumber: PerMenPUPR No. 4/2017)

\section{HASIL DAN PEMBAHASAN}

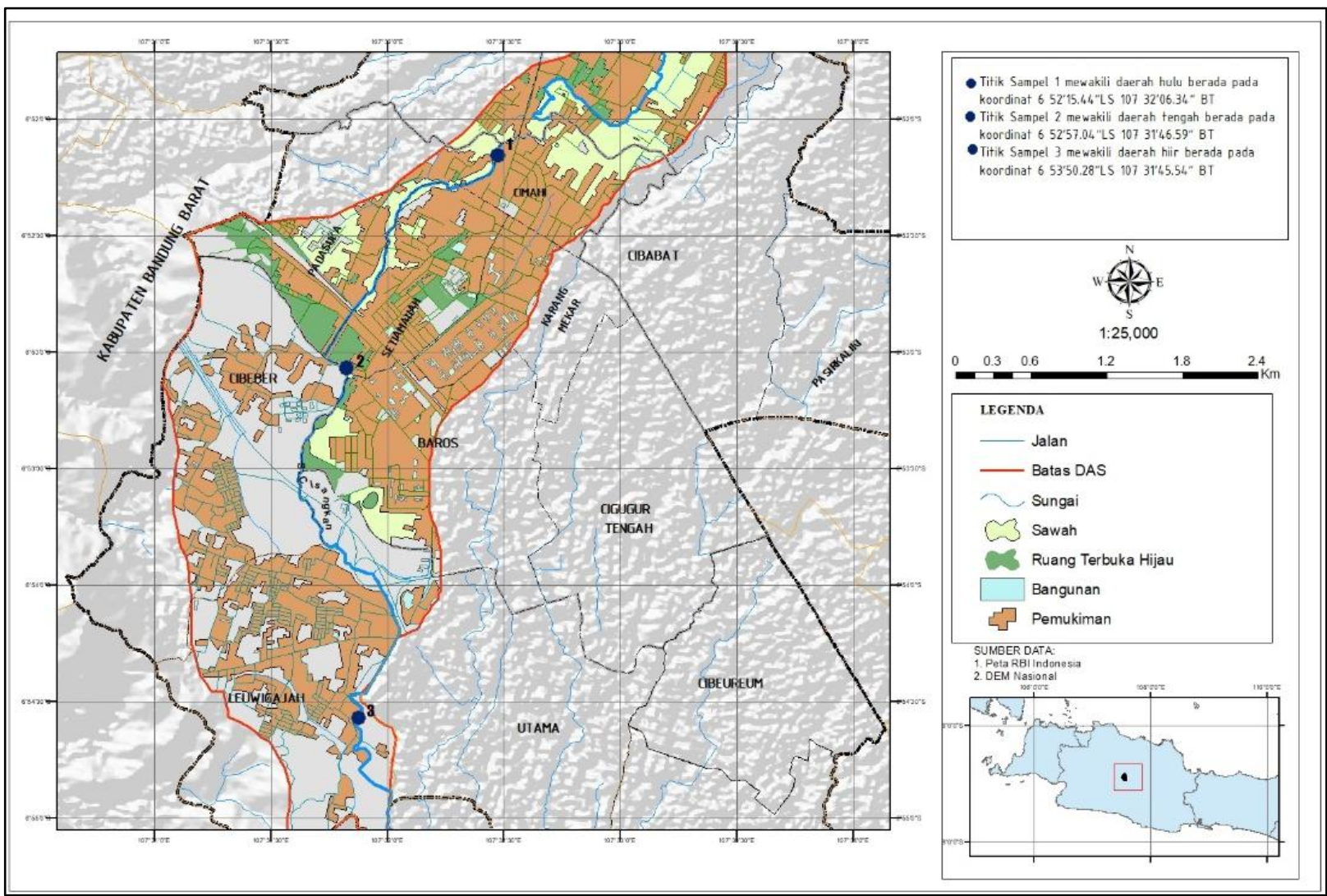

Gambar 2 Peta DAS Cisangkan 


\subsection{Gambaran Umum Wilayah Perencanaan}

DAS Cisangkan merupakan DAS terbesar di Kota Cimahidengan aktivitas di dominasi oleh kegiatan domestik dan industri. Petas DAS Cisangkan dapat dilihat pada Gambar 2. Tahun 2019 dilakukan pemantauan kualitas air Sungai Cisangkan di tiga titik bagian hulu, tengah, dan hilir dengan kesimpulkan mutu air sudah tercemar dengan katagori sedang hingga berat.

\subsection{Penapisan SPALD}

Berdasarkan hasil analisis kualitas air Sungai Cisangkan menyatakan bahwa parameter yang melebihi baku mutu kualitas air kebanyakan merupakan parameter yang dihasikan dari limbah domestik. Upaya pengendaliannya dengan cara melakukan perencanaan SPALD. Langkah pertama adalah melakukan proses penapisan yang akan diuraikan pada pembahasan selanjutnya.

Penentuan jumlah penduduk merupakan Langkah utama dalam penapisan. Kota Cimahi memiliki total kelurahan sebanyak 15 (lima belas) dimana 10 kelurahan diantaranya masuk kedalam wilayah DAS Cisangkan. Kepadatan penduduk total kota dapat dilihat dari data BPS Kota Cimahi, sedangkan kepadatan penduduk yang masuk ke dalam DAS Cisangkan dilihat dari luas area kelurahan yang masuk kedalam wilayah DAS di bandingkan dengan jumlah penduduk keluarahan tersebut. Hasil perbandingan inilah yang akan menentukan kepadatan penduduk DAS Cisangkan dapat dilihat pada Tabel 1.

Tabel 1 Kepadatan Penduduk DAS Cisangkan

\begin{tabular}{cccc}
\hline Kecamatan & Kelurahan & $\begin{array}{c}\text { Penduduk wilayah DAS } \\
\text { (jiwa) }\end{array}$ & $\begin{array}{c}\text { Kepadatan Penduduk } \\
\text { wilayah DAS (jiwa/ km } \mathbf{~}^{\text {) }}\end{array}$ \\
\hline \multirow{2}{*}{ Cimahi Utara } & Citeureup & 19.936 & 6.230 \\
& Cipageran & 1.446 & 245 \\
\hline \multirow{6}{*}{ Cimahi Tengah } & Baros & 11.130 & 4.946 \\
& Karangmekar & 9.472 & 7.230 \\
& Padasuka & 26.295 & 13.280 \\
& Setiamanah & 24.956 & 18.084 \\
& Cimahi & 10.348 & 12.319 \\
\hline \multirow{6}{*}{ Cimahi Selatan } & Cibeber & 20.542 & 6.225 \\
& Leuwigajah & 37.868 & 9.710 \\
& Utama & 1.197 & 386 \\
\hline
\end{tabular}

Sumber: Pengolahan Data BPS Kota Cimahi, 2020

Jenis SPALD yang akan digunakan menurut penapisan kepadatan penduduk adalah, bila suatu daerah memiliki kepadatan penduduk lebih besar dari 15.000 jiwa $/ \mathrm{km}^{2}$, maka jenis SPALD yang digunakan adalah SPALD-Terpusat. Berdasarkan hasil Analisis yang disajikan pada Tabel 1, kelurahan yang memiliki kepadatan $>15.000$ jiwa $/ \mathrm{km}^{2}$ adalah Setiamanah dengan kepadatan penduduk $18.084 \mathrm{jiwa} / \mathrm{km}^{2}$. Hal ini disebabkan karena Kelurahan Setimanah seluruh daerahnya masuk ke dalam DAS Cisangkan sehingga kepadatan penduduk total kelurahan ini juga merupakan kepadatan penduduk yang masuk ke dalam wilayah DAS. Kelurahan lainnya memiliki kepadatan yang kurang dari $15.000 \mathrm{jiwa} / \mathrm{km}^{2}$ sehingga jenis SPALD yang akan digunakan adalah SPALD-Setempat. Peta wilayah DAS Cisangkan berdasarkan kepadatan penduduknya dapat dilihat pada Gambar 3. 


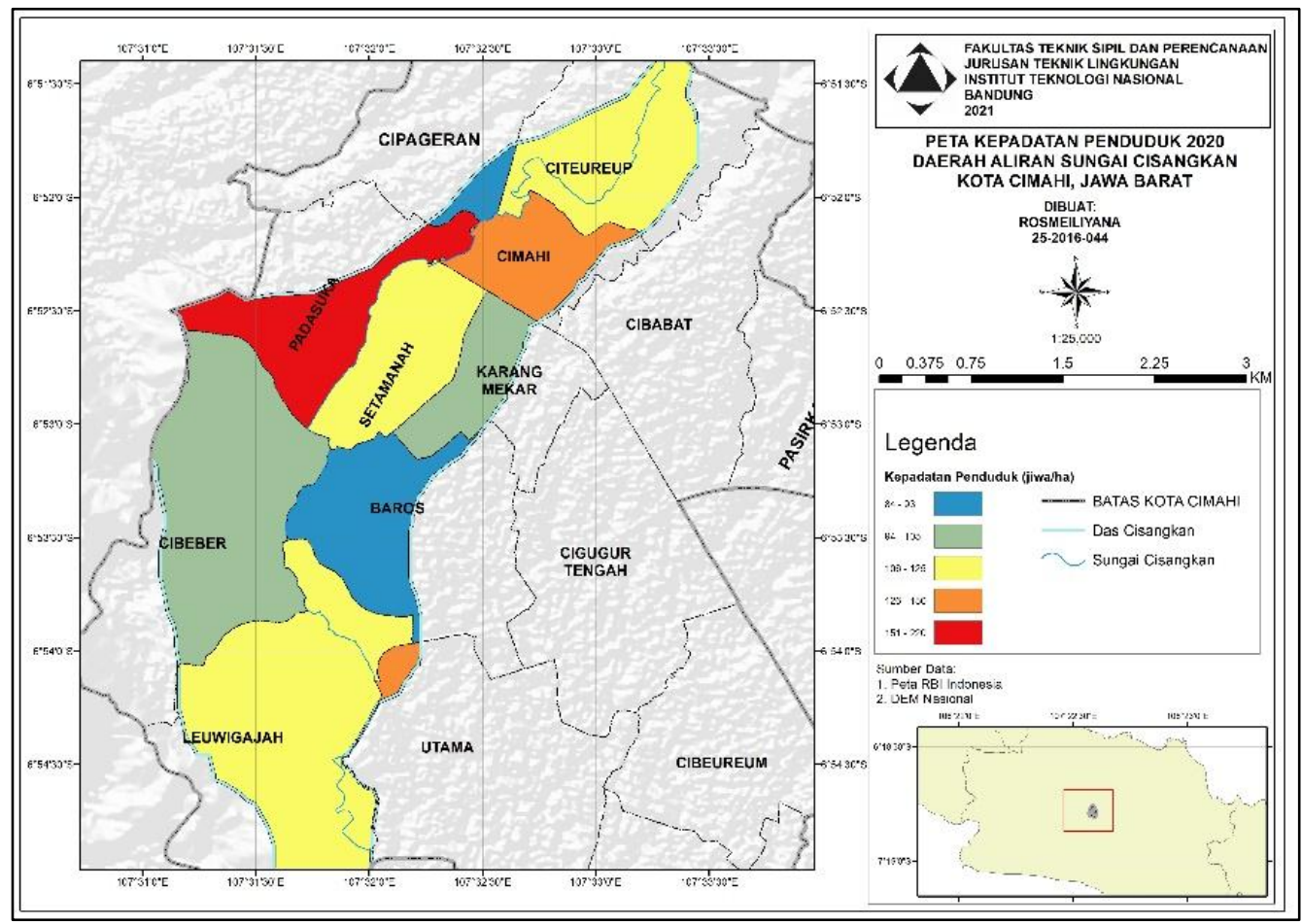

Gambar 3 Peta Kepadatan Penduduk DAS Cisangkan Tahun 2020

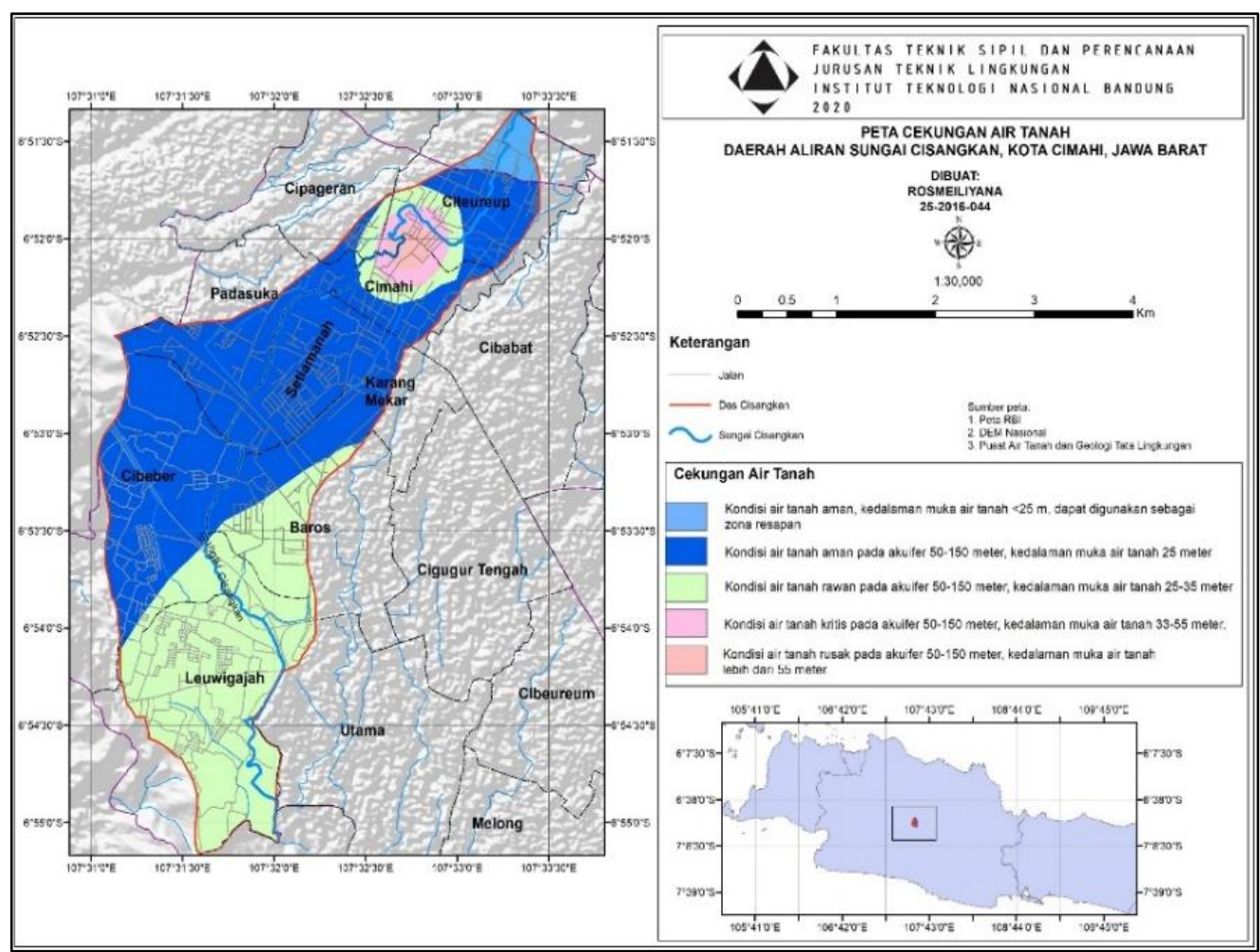

Gambar 4 Peta Kedalaman Muka Air Tanah DAS Cisangkan

Langkah kedua yaitu penentuan muka air tanah DAS Cisangkan menggunakan peta cekungan air tanah yang didapat dari Pusat Air Tanah dan Geologi Tata Lingkungan. Ratarata wilayah DAS Cisangkan memiliki kedalaman air tanah di atas $2 \mathrm{~m}$ sehingga dapat menerapkan jenis pengelolaan air limbah domestik dengan SPALD-Setempat, dikarenakan wilayahnya DAS memiliki kedalaman muka air tanah yang bisa dijadikan daerah resapan, 
sehingga aman untuk penggunaan SPALD jenis setempat. Gambar 4 menunjukkan kondisi cekungan air tanah di DAS Cisangkan.

DAS Cisangkan memiliki wilayah dengan kondisi jenis batu yang mendominasi adalah berbatu apung dan tufa pasir dimana jika jenis tanah berpasir maka memperkecil pori sehingga akan menghampat proses penyerapan. Batu apung merupakan batu yang dihasilkan dari aktivitas vulkanik dan memiliki pori-pori yang besar sehingga dapat mempermudah proses penyerapan air. Berdasarkan data tersebut dapat disimpulkan bahwa terdapat dua area yang memiliki tingkat permeabilitas yang berbeda. Kelurahan dengan jenis batu tufa pasir adalah Citeureup, Cimahi, sebagian Padasuka, sebagian Setiamanah dan sedikit area dari Karangmekar. Ada kemungkinan bahwa kelurahan ini akan menggunakan jenis SPALD-Terpusat. Sisanya menggunakan jenis SPALD-Setempat karena permeabilitasnya tinggi (RPJMD Kota Cimahi, 2018). Peta jenis batuan yang ada di wilayah DAS Cisangkan, dapat dilihat pada Gambar 5.

DAS Cisangkan memiliki kemiringan lahan yang relatif datar, dimana hampir seluruh wilayahnya berada pada area landai. Beberapa daerah memiliki tingkat kemiringan curam seperti di daerah Kelurahan Leuwigajah, dan Padasuka. Sebagian besar wilayah DAS Cisangkan berada pada kemiringan $0-8 \%$ dan hampir seluruh daerah memiliki kemiringan diatas $2 \%$ sehingga dapat digunakan jenis pengelolaan limbah domestik dengan cara SPALDTerpusat. Kondisi lereng DAS Cisangkan yang lebih besar dari $2 \%$ akan memudahkan pada saat proses penentuan jalur pelayanan penyaluran air limbah karena dapat menggunakan metode penyaluran secara gravitasi (RPJMD Kota Cimahi, 2018). Peta kemiringan lahan DAS Cisangkan dapat dilihat pada Gambar 6. Langkah terakhir dari proses penapisan yaitu penentuan kemampuan pembiayaan SPALD. Pemerintah Kota Cimahi telah memiliki anggaran tersendiri untuk pengelolaan air limbah melalui APBD tahun 2019, sehingga untuk kemampuan pembiayaan dalam pembuatan SPALD pemerintah dikatakan sanggup untuk melalukan jenis pengelolaan air limbah khususnya air limbah domestik.

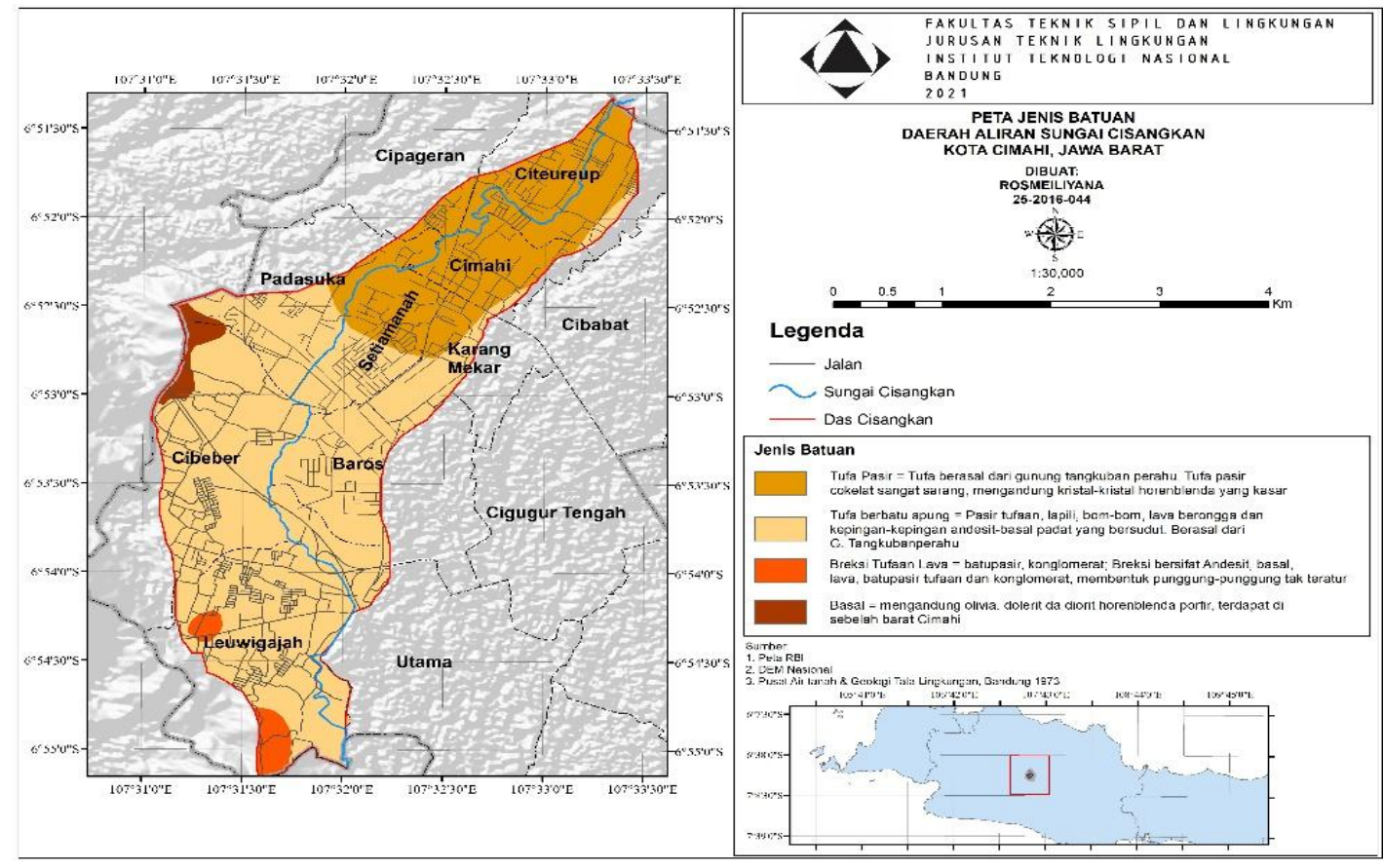

Gambar 5 Peta Jenis Batu DAS Cisangkan 


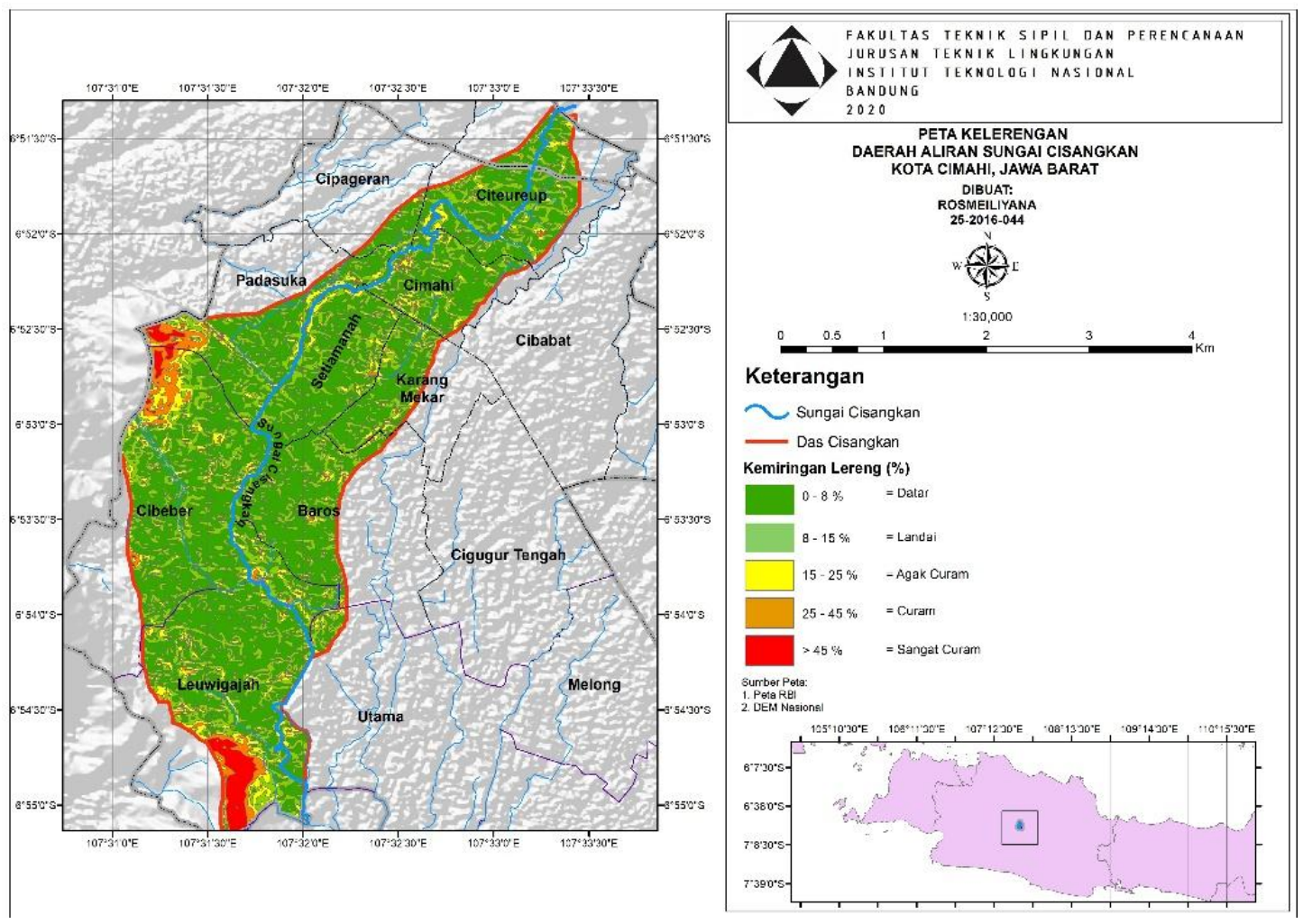

Gambar 6 Peta Kemiringan Lahan DAS Cisangkan

Berdasarkan hasil penapisan secara bertahap yang telah dibahas sebelumnya, penentuan daerah yang akan melakukan pengelolaan air limbah dengan jenis SPALD-T atau SPALD-S akumulasinya dapat dilihat pada Tabel 2.

Sepuluh daerah yang ada di wilayah DAS Cisangkan, terdapat 1 kelurahan yang bisa menerapkan jenis SPALD-T karena kepadatan penduduknya lebih besar dari 15.000 jiwa $/ \mathrm{km}^{2}$. Tahap dua, dimana dilihat dari kondisi kedalaman muka air tanah, wilayah DAS Cisangkan memiliki kedalaman muka air tanah yang lebih besar dari $2 \mathrm{~m}$, sehingga dapat menerapkan jenis SPALD-S. Kelurahan Setiamanah, yang di tahap satu ada pertimbangan menggunakan jenis SPALD-T, ditahap dua ternyata hasil penapisan menunjukkan bahwa Kelurahan Setiamanah bisa menerapkan jenis SPALD-S. Hingga tahap dua, dapat disimpulkan bahwa DAS Cisangkan akan menerapkan jenis pengelolaan limbah domestik dengan SPALD-S.

Tabel 2 Hasil Penapisan Penentuan Jenis SPALD DAS Cisagkan

\begin{tabular}{cccccc}
\hline Kelurahan DAS & Tahap 1 & Tahap 2 & Tahap 3 & Tahap 4 & Tahap 5 \\
\hline Citeureup & 2 & 2 & 1 & 1 & 1 \\
\hline Cipageran & 2 & 2 & 1 & 1 & 1 \\
\hline Baros & 2 & 2 & 2 & 1 & 1 \\
\hline Karangmekar & 2 & 2 & 2 & 1 & 1 \\
\hline Padasuka & 2 & 2 & 2 & 1 & 1 \\
\hline Setiamanah & 1 & 2 & 1 & 1 & 1 \\
\hline Cimahi & 2 & 2 & 1 & 1 & 1 \\
\hline Cibeber & 2 & 2 & 2 & 1 & 1 \\
\hline Leuwigajah & 2 & 2 & 2 & 1 & 1 \\
\hline Utama & 2 & 2 & 2 & 1 & 1 \\
\hline
\end{tabular}


Keterangan: Tahap 1 = Kepadatan Penduduk, Tahap 2 = Cekungan air tanah, Tahap $3=$ Permeabilitas, Tahap $4=$ Kemampuan pembiayaan, dan Tahap $5=$ Kemiringan Lahan

No. 1 = SPALD-T dan No. 2 = SPALD-S

Tahap 3 penapisan, yaitu berdasarkan permeabilitas, ada beberapa daerah yang perlu dipertimbangkan jika ingin menggunakan SPALD-T, yaitu untuk kelurahan Citeureup, Cipageran, Setiamanah, dan Cimahi. Semua kelurahan ini memiliki tanah dengan jenis batuan tufa pasir, sehingga permeabilitas tanah kecil karena porositas tanah yang kecil sehingga perlu dipertimbangkan jika ingin menggunakan SPALD-S. Tahap 4, Kota Cimahi memiliki anggaran tersendiri bagi pengelolaan air limbahnya, baik air imbah domestik dan non-domestik sehingga pada tahap ini, kemampuan pemerintah dianggap mampu untuk membuat pengelolaan limbah domstik jenis SPALD-T. Penapisan terakhir yaitu kemiringan lahan, wilayah DAS Cisangkan berada di lereng dengan kemiringan (slope) lebih besar dari $2 \%$ sehingga aman untuk menggunakan SPALD-T

Dari proses penapisan, wilayah DAS Cisangkan akan menggunakan jenis SPALD yang setempat. Hasil pemetaan dapat dilihat pada Gambar 7. Untuk jenis SPALD-Setempat, opsi yang bisa dipilih berdasarkan PerMenPUPR No. 4/2017 adalah skala individual dapat berupa cubluk kembar, tangki septik dengan bidang resapan, biofilter dan unit pengolahan air limbah fabrikasi dan skala komunal yang diperuntukkan untuk 2 sampai dengan 10 unit rumah tinggal dan mandi cuci kakus (MCK), dapat berupa permanen dan non permanen (mobile toilet).

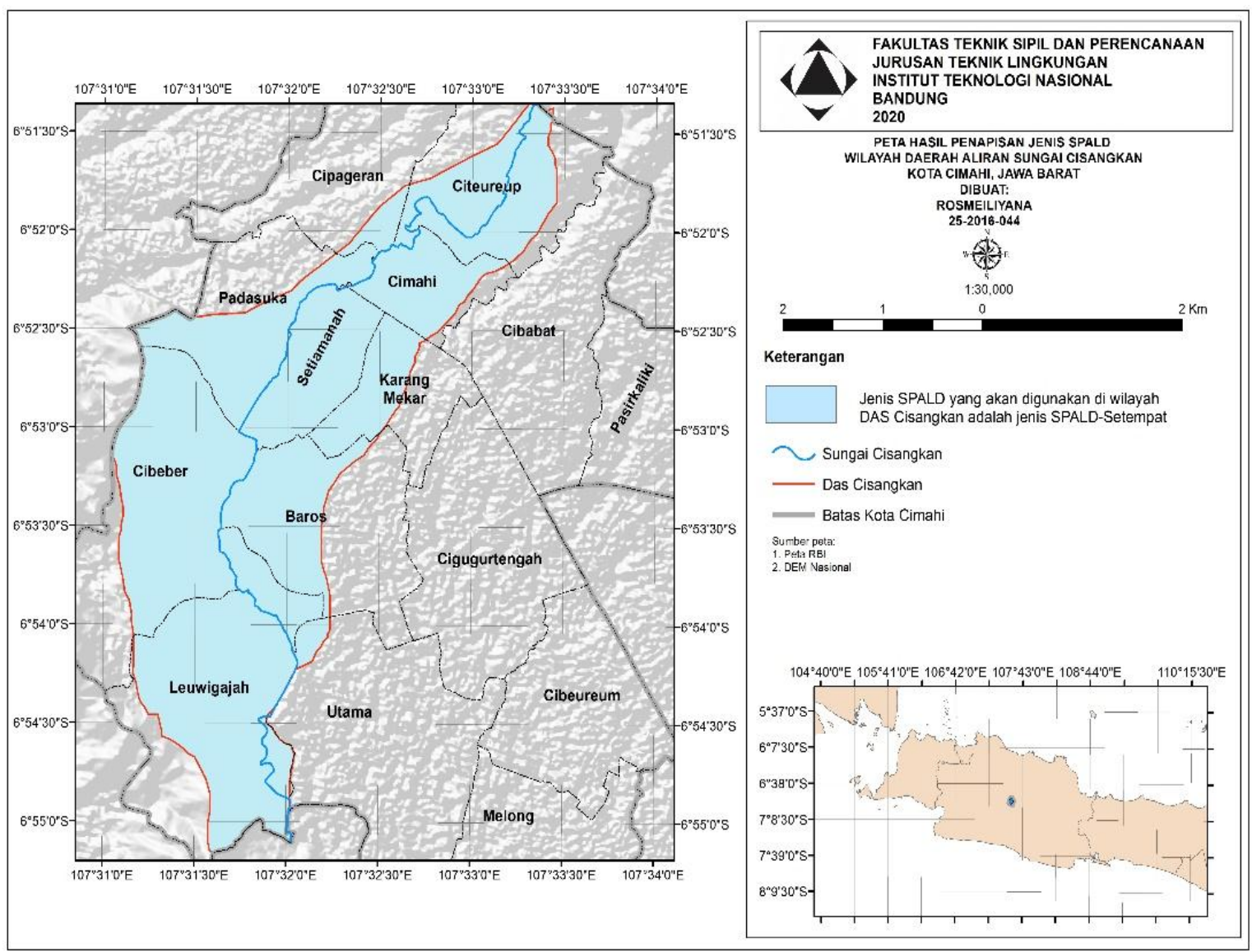

Gambar 7 Peta Penentuan Jenis SPALD DAS Cisangkan 
Berdasarkan kondisi kependudukan dan kemampuan pembiayaan yang dimiliki oleh Pemerintah Kota Cimahi, pertimbangan pemilihan jenis SPALD dapat dilakukan dengan melihat aspek kemiringan lahan dan potensi wilayah perencanaan dalam meningkatkan kualitas pengelolaan air limbah domestik. Pertimbangan lain juga adalah terkait ketersediaan lahan untuk membuat jenis SPALD-T dimana nantinya akan di bangun Instalasi Pengolahan Lumpur Tinja (IPLT) di satu daerah kosong, milik pemerintah atau milik masyarakat dengan sistem kontrak berbayar, dan nantinya akan mengalirkan air limbah domestik warga, khususnya yang black water menuju SPALD-Terpusat. Hasil pertimbangan pemilihan jenis SPALD, dapat dilihat pada Gambar 8.

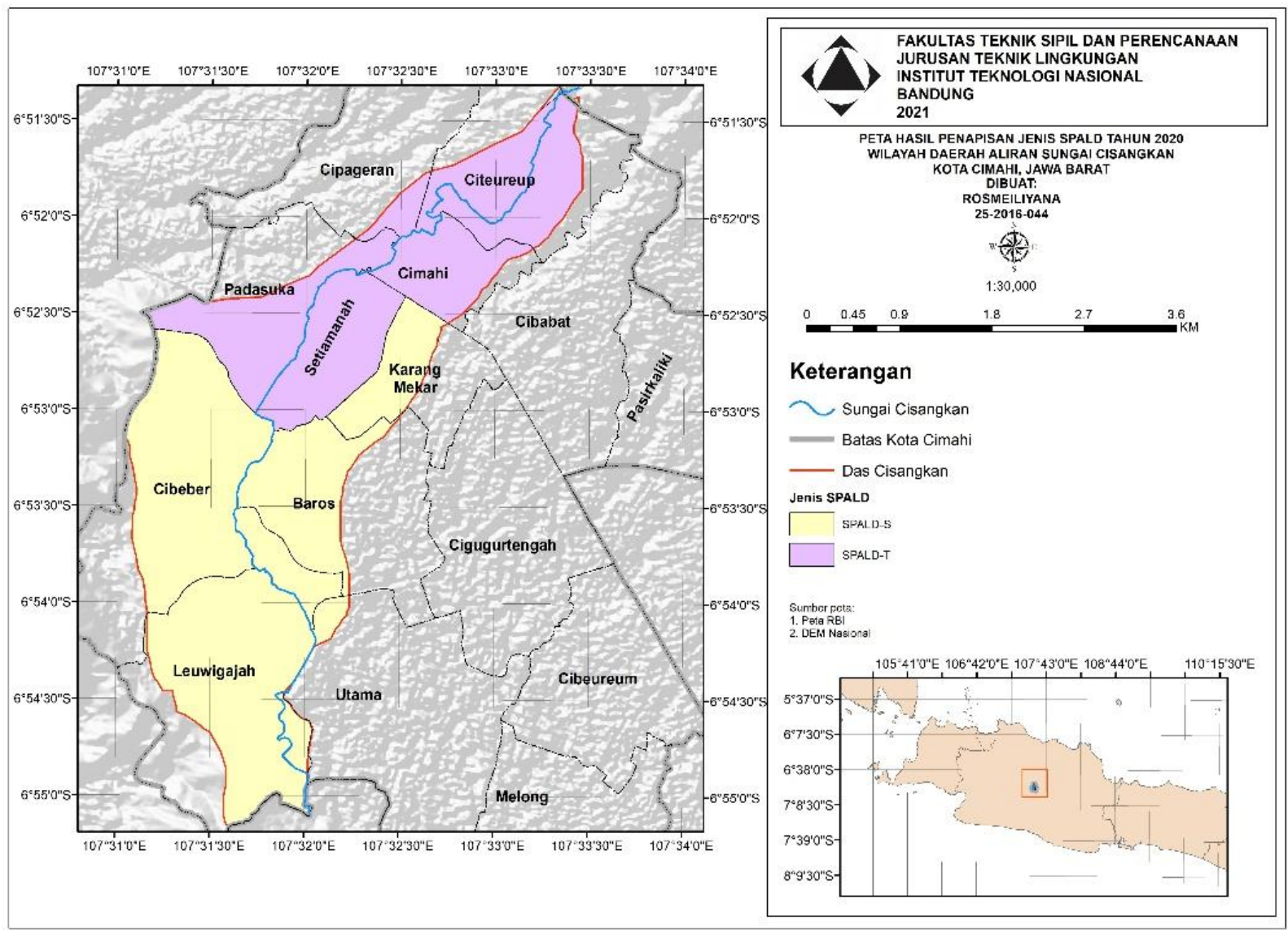

Gambar 8 Peta Pertimbangan Jenis SPALD DAS Cisangkan

\section{KESIMPULAN}

Berdasarkan hasil penelitian kesimpulan yang dapat diambil adalah sumber pencemar yang masuk ke dalam Sungai Cisangkan didominasi oleh sektor domestik yaitu dari aktivitas penduduk yang tinggi sehingga banyak timbulan air limbah domestik yang dikeluarkan dan masuk ke Sungai Cisangkan. Status mutu Sungai Cisangkan adalah tercemar sedang hingga tercemar berat. Hal ini menyatakan bahwa di Sungai Cisangkan perlu dilakukannya pengelolaan terhadap air limbah yang masuk ke dalam sungai supaya tidak semakin menurunkan kualitas air Sungai Cisangkan. Upaya pengelolaan yang disarankan adalah pengelolaan dengan SPALD dimana terdapat dua pilihan yaitu secara terpusat (off-site) atau setempat (on-site). Penentuan jenis pelayanan disesuaikan dengan kondisi penapisan masing-masing kelurahan yang masuk ke dalam DAS Cisangkan. Jenis SPALD yang akan digunakan adalah SPALD-Terpusat di Kelurahan Citeureup, Cipageran, Cimahi, dan 
Setiamanah. Sedangkan sisanya akan menerapkan jenis SPALD-setempat yaitu Kelurahan Padasuka, Baros, Karangmekar, Leuwigajah dan Utama.

\section{DAFTAR RUJUKAN}

Aini, N. N. U. (2019). Kajian Teknis Dan Sosial Pengelolaan Air Limbah Domestik Di Kecamatan Sedati Kabupaten Sidoarjo. UIN SUNAN AMPEL SURABAYA

Arinda, A. dan Wardhani, E. (2018) Analisis Profil Konsentrasi Pb di Air Waduk Saguling. Rekayasa Hijau: Jurnal Jurnal Teknologi Ramah Lingkungan. 2(3). 213-219

Anggraini. Y. dan Wardhani. E. (2021) Studi Mutu Air Sungai Cibaligo Kota Cimahi Provinsi Jawa Barat dengan Metode Indeks Pencemar. Jurnal Serambi Engineering. 6 (1). 14781487

Desriyan, R. dan Wardhani, E. (2015) Identifikasi Pencemaran Logam Berat Timbal (Pb) pada Perairan Sungai Citarum Hulu Segmen Dayeuhkolot sampai Nanjung Jurnal Reka Lingkungan. 1(3).

Kementerian Pekerjaan Umum dan Perumahan Rakyat. (2017). Peraturan Menteri No 4 tahun 2017 tentang Penyelenggaraan Sistem Pengelolaan Air Limbah Domestik.

Kusumawardhani. A.A, Wardhani. E, dan Halomoan. N. (2019). Penentuan Sistem Pengelolaan Air Limbah Domestik Di Kecamatan Bekasi Timur, Kota Bekasi. ENVIROSAN. Jurnal Teknik Lingkungan: 2(1)

Pemerintah Kota Cimahi. (2020). Dokumen Informasi Kinerja Pengelolaan Lingkungan Hidup Daerah (DIKPLHD) Kota Cimahi Tahun 2020. Wali Kota Cimahi.

Pemerintah Kota Cimahi Kota Cimahi. (2018). Rencana Pembangunan Jangka Menengah Daerah Kota Cimahi Tahun 2017-2022. Cimahi.

Rachmaningrum, M, Wardhani. E, dan Pharmawati. K, (2015) Konsentrasi Logam Berat Kadmium (Cd) pada Perairan Sungai Citarum Hulu Segmen Dayeuhkolot-Nanjung. Jurnal Reka Lingkungan. 3(1). 1-10.

Sulistiowati, L.A dan Wardhani. E. (2018) Kajian Dampak Pembuangan Air Limbah Industri PT. X Terhadap Sungai Cikijing di Provinsi Jawa Barat. Rekayasa Hijau: Jurnal Teknologi Ramah Lingkungan. 2 (1). 20-30.

Uyun. Q, Wardhani. E, Halomoan. N. (2019) Pemilihan Jenis Sistem Pengelolaan Air Limbah Domestik di Kecamatan Bekasi Selatan. Rekayasa Hijau. Jurnal Teknologi Ramah Lingkungan. 3(2).157-168

Wardhani, E dan Sulistiowati, L.A. (2018) Kajian Daya Tampung Sungai Citarik Provinsi Jawa Barat. Rekayasa Hijau: Jurnal Teknologi Ramah Lingkungan. 2(2). 20-30. 
Wardhani, E. Notodarmojo, S dan Roosmini, D. (2014) Pencemaran Kadmium di Sedimen Waduk Saguling Provinsi Jawa Barat. Jurnal Manusia dan Lingkungan Pusat Studi Lingkungan Hidup Universitas Gadjah mada (PSLH UGM). 23(3). 285-294.

Wardhani, E. Notodarmojo, S dan Roosmini, D. (2017a) Heavy Metal Speciation in Sediments in Saguling Lake West Java Indonesia. International Journal of GEOMATE ISSN: 21862990 Japan Bulan Juni 2017 Vol 12 Issue 34 pp 146-151.

Wardhani, E. Notodarmojo, S dan Roosmini, D. (2017b). Status heavy metal in Sediment of Saguling Lake, West Java. Province. International Journal IOP Conferences Series: Earth and Environmental Science ISSN: 17551315, 17551307 Volume 60 tahun 2017, 012035.

Wardhani, E. Notodarmojo, S dan Roosmini, D. (2018) Assessment of heavy metal contamination in the water of Saguling Reservoir West Java Province Indonesia. E3S Web of Conferences 73, 06009 (2018).

Wiguna. A.S , Wardhani. E, dan Halomoan. N (2019). Penapisan Perencanaan Sistem Penyaluran Air Limbah Domestik Kecamatan Beji Kota Depok. ENVIROSAN. Jurnal Teknik Lingkungan. 2(2). 63-69

Zorpas, A. A., Lasaridi, K., Voukkali, I., Loizia, P., \& Chroni, C. (2015). Household waste compositional analysis variation from insular communities in the framework of waste prevention strategy plans. Waste Manag, 38, 3-11. doi:10.1016/j.wasman.2015.01.030 